\title{
Environmental Impact Assessment in Sustainable Water Resources Development: Major Issues of Consideration
}

\author{
Tena Bekele Adgolign* and Srinivasa Rao GVR
}

\section{Department of Civil Engineering, College of Engineering (A), Andhra University, Visakhapatnam-530003,} Andhra Pradesh, India

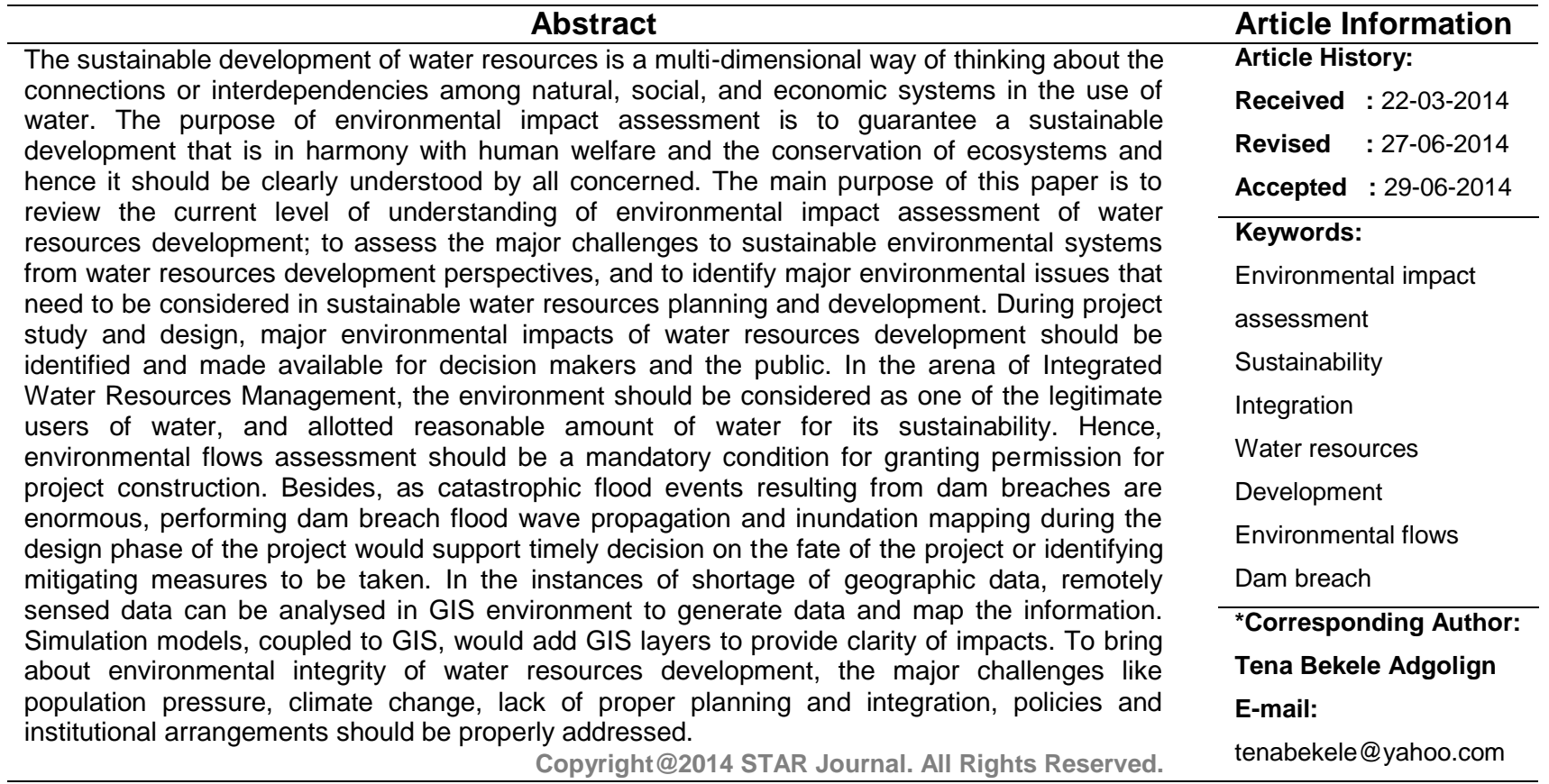

\section{INTRODUCTION}

For all of human history, the Earth has sustained human beings by providing food, water, air, and shelter. People have been altering natural occurrences, including water resources, in a way it suits their will. However, sustainable water resource systems are expected to fully contribute to the objectives of the society across generations, while maintaining their ecological, environmental, and hydrological integrity (The American Society of Civil Engineers (ASCE), 1998). Here, maintenance of their environmental integrity is a very important criteria to be met for the water resources systems to be sustainable, because environment is nothing but 'surrounding conditions influencing development or growth' (Jain and Singh, 2003).

The alternation of natural occurrence of resources to fulfil man's needs is development, which, according to Flint (2004), means improving or bringing to a more advanced state. Maintenance of the ecological, environmental and hydrologic integrity should be achieved while the resource is put to the beneficial use of man. In order to achieve this, development should result in improved human's productive power and progressive socio-economic betterment without damaging or undermining the environment, and growing beyond ecological carrying capacity (Flint, 2003 cited in Flint, 2004).

The sustainable development of water resources is a multi-dimensional way of thinking about the connections or interdependencies among natural, social, and economic systems in the use of water (Flint, 2004). The ecosystem is one component of these interdependent and interacting systems. Where such interdependencies and interactions exist, it is evident that human interference in one element will ultimately affect the whole environmental system. If the current pattern of ecosystems' use continues, there might be serious decline in their ability to yield the range of benefits, such as clean water and stable climate that they have been providing so far (Jain \& Singh, 2003). 
The main purpose of this paper was to review the current level of understanding of environmental impact assessment of water resources development, and the major challenges to sustainable environmental systems from the perspective of water resources development. The paper is limited to assessing the major parameters that need special attention; and it does not cover the wide range of environmental impacts of water resources development. The major environmental issues that need to be considered in sustainable water resources planning and development are also identified.

\section{METHODOLOGY}

To achieve the objectives of the paper, extensive review of previous works of different scholars on EIA of water resources development was made. For some EIA parameters which are believed to have significant implication on the sustainability of water resources development, some instances of current practices in some countries were cited in order to clearly show the gap between the principles and practices, and thereby propose future directions.

\section{Environmental Impact Assessment}

Environmental impact assessment (EIA) is a decisionmaking process that systematically evaluates the possible significant (negative or positive) effects that a proposed project action may exert on the natural, social and human environment of a particular geographic area (Lei and Hilton, 2013). It is a process that analyzes and evaluates the impacts that human activities can have on the environment. Its purpose is to guarantee a sustainable development that is in harmony with human welfare and the conservation of ecosystems (Toro, et al., 2013).

EIA is a decision-making process that evaluates the possible significant effects that a proposed project may exert on the environment (Lei and Hilton, 2013). Toro, et al. (2013) state that EIA is the technical key to incorporating concepts such as the precaution principle and to preventing the loss of natural (and manmade) resources, which is evidently the main goal of sustainable development in decision-making.

The physical and biological effects of river development schemes arise from the obstacle the dam causes to the natural flow, the climate changes caused by the reservoir interacting with the overlying atmosphere, the effects of the structure on the water in and near the reservoir, and slides and ground tremors caused by the stored water (Abbasi, 2001). Water use has been growing at more than twice the rate of population increase in the last century, and, although there is no global water scarcity as such, an increasing number of regions are chronically short of water (United Nations, 2006). The world's net cultivated area has grown by 12 percent over the last 50 years, mostly at the expense of forest, wetland and grassland habitats, while the global irrigated area has doubled (FAO, 2011). Though the impact of the schemes on the social, economic and physical environment could be both beneficial and adverse, the cumulative effect should be positive so that the lost natural and man-made resources are compensated anyway.

\section{Environmental Impact Assessment of Water Resources Development and Integrated Water Resources Management}

As one of the legitimate users of water (Hirji \& Davis, 2009), the environment should be allotted sufficient amount of water for its sustainability, based on seasonal variability in water demand. Whenever there are competing needs of water resources, maximization of benefits and minimization of costs would largely depend on a water allocation decision-making procedure which incorporates views of different stakeholder, perspectives and is based on informed assessments of the trade-offs (McCartney and Awulachew 2006 cited in McCartney, et al., 2010). Besides, participatory methods are widely seen as essential to address the difficulties of environmental policy and decision-making (Lienert, et al., 2013).

As much as the adaptive ecosystem approach requires a holistic view of the ecological and socioeconomic aspects of an entire landscape, it also requires an integrated institutional and fully participatory planning and decision making process (ASCE, 1998). Specially, in view of increasing future dynamics and climate change, a more participatory and long-term planning approach is required (Lienert, et al., 2013). Consequently, in contrast to the past, (environmental) planning needs to be much more integrated across a range of levels and scales, with much greater consideration of the full range of possible options and the potential implications of climate change (McCartney, et al., 2013).

It goes without saying that development projects are meant to improve the livelihoods of the people. However, it is a mere fact that the overall national benefit of the project overweighs local social and environmental damages. This may be dismaying to the local community. Hence, the community affected by a development project should be previously informed so that its members can participate in the decision-making processes (Toro, et al., 2013).

Sustainable water resources development has a great role to play in ensuring the integrity of ecosystems (Acreman and J.Dunbar, 2004). This was highlighted in the declaration from the Second World Water Forum in The Hague in 2000. Integrated water resources management considers the environment to be a legitimate user of water and integrates environmental flows into the implementation of IWRM (Hirji \& Davis, 2009). Conversely, the 2002 Johannesburg World Summit on Sustainable Development reinforced the role of environmental protection as a key pillar of sustainable development (Acreman and Dunbar, 2004). Because, the removal of water from rivers, and other changes to the flow regimes, invariably result in a loss of ecosystem function and resilience (Bunn and Arthington 2002 cited in Nel, et al., 2011).

The greater the divergence from a natural flow regimein terms of volume and timing-the greater the ecosystem changes (Poff and Zimmerman, 2010 cited in Nel, et al., 2011); hence, the less the sustainability of the system. If the legitimate right of the ecosystems as a water user is acknowledged, this will make a remarkable step forward towards the achievement of the sustainability of water resources development that nations have been longing for. Therefore, environmental flows assessment and allocation of water for ecological water demand should be mandatory before granting permission for construction of water resources development. 


\section{Major Environmental Implications of Water Resources} Development

Major Environmental Impacts of Water Resources

Projects:The impacts caused by construction of dams and reservoirs include changes in the microclimate, loss of vegetation cover, soil erosion, variation in water table and enhanced seismic activities due to pressure of water (Siddiqui, et al., 2008). Although the development of water resources through dams (small and large), interbasin transfers, aquifer storage and recovery, levees and dikes, and boreholes provides a buffer against climate variability (Hirji \& Davis, 2009), ill-conceived water storage structures constructed today will be a waste of scarce financial resources, and may aggravate unpleasant climate change impacts rather than mitigating it (McCartney, et al., 2013). The realities of climate change are such that if the performance of agricultural water storage is to be enhanced in the future, much closer attention must be paid to planning and management (ibid.).

The environmental impacts which a water resources project is likely to have can be classified as:

- Impacts within and around the area covered by dam and reservoir;

- Downstream effects caused by alteration in hydraulic regime.

- Regional effects in terms of overall aspects including resources use and socio-economic impacts.

Though water resources development activities date back to thousands of years, only during the last 4-5 decades, both the size and number of projects have increased significantly (Jain and Singh, 2003). With the doubling of the global irrigated area over the last 50 years, withdrawals for agriculture have been rising, resulting in total global water withdrawals of only a share-about 9 percent of internal renewable water resources (FAO, 2011). This figure seems to represent small proportion; however, on-stream and off-stream environmental impacts due to the rapid expansion of irrigated lands and increasing withdrawals of freshwater are inevitable, as irrigation and water resource development can also cause social and environmental problems (Stockle, 2001).

Particularly, in the past, evaluation of environmental impacts was inadequate, and the impact on poor people living both upstream of dams (in the area inundated by the reservoir) and downstream of dams (where flows were modified) has rarely been addressed properly. Consequently, the legacy of large dams is mixed (WCD 2000 cited in IWMI, 2013). Hence, water resources projects impact assessment is very important for protection, conservation or enhancement of the existing environmental conditions (Siddiqui, et al., 2008). Prediction of impacts involves projecting the baseline environmental setting into the future with and without project and then performing necessary computations for predicting real impacts of the proposed development (ibid.). Its application involves the use of attributes to identify and evaluate possible environmental changes caused by a project, construction, or other human activity.

Water resources development projects have both beneficial and adverse environmental impacts. All river development schemes are built to produce obvious beneficial effects for society, the main ones being irrigation, land reclamation in river flood plains and tidal areas, domestic and industrial water supply, flood control and improved dry weather flow in rivers, hydroelectricity, navigation, recreational activities, and so on (Abbasi, 2001). The benefits of irrigation have resulted in lower food prices, higher employment and more rapid agricultural and economic development. The spread of irrigation has been a key factor behind the near tripling of global grain production since 1950 (Stockle, 2001).

The apportioning of limited water resources embeds trade-offs between different people, between substantially different uses of water, between water resources and other resources, and between the present and future generation of population (Griffin, 2006), George, et al. (2008). It is evident that on the course of meeting human water demands for socio-economic betterment, water will be abstracted and diverted from its natural course, or pumped out from the aquifers, imposing distortions of varying extents on the natural occurrence of water. This will eventually result in some environmental impacts. Abbasi (2001) mentions that the diversion and dying up of mountain rivers is detrimental to fishing and is an eyesore. Such projects must be (planned and) built to higher standards and with more accountability to local people and their environment than in the past (Griffin R. , 2006).

As a water management strategy, past water resource planning has focused mostly on large dams, the construction of which is often controversial although they have made an important and significant contribution to human development (McCartney, et al., 2013). They are often seen as essential for national economic development, and their macro-economic benefits tend to be highlighted while environmental considerations and especially local economic impacts and social impacts may be less adequately evaluated (Baba \& Hirose, 2014). However, dams and reservoirs, aqueducts, river diversions, major irrigation projects, industrial and domestic diversions, groundwater pumping etc have a major hydrological impact which could affect both present and future generations and wildlife (George, et al., 2008).

Hence, there is no doubt that on one side of the balance sheet, such projects have sometimes meant ecologically stressful situations for animal and plant species, the forced removal of local peoples, deforestation and flooding of land areas, and other environmental problems; and problems ranging from the loss of fertile soils, increases of greenhouse gas emissions, creation of environments for diseases and even local (and regional) climate changes have been claimed (ASCE, 1998). In addition to these, the impacts caused by construction of dams and reservoirs include variation in water table and enhanced seismic activities due to pressure of water (Siddiqui, et al., 2008).

Thus, the administrative control and management activities that strive to match the demand for water by the socio-economic system with the supply of water system, though is the fundamental goal of water resource planning and management (Dong, et al., 2013), should not compromise ecosystems sustainability. As a remedy to the detrimental effects of river diversion on fishing, Abbasi (2001) proposes the allocation of an adequate guaranteed compensation flow through the dam; the amount to be varied with daylight and night hours and from season to season, as required by tourist amenity considerations. 
However, the term 'compensation' tends to compromise the rightful water share of the environment; and if sustainability of development and human welfares are truly sought, it could still be argued that the environment being legitimate user of water (Hirji \& Davis, 2009), should be acknowledged universally. Hence, environmental flows assessment and water allocation for the environment are worth considering in EIA of water resources development.

Environmental Flows Assessment as a Component of EIA: The term 'environmental flows' is now commonly used to refer to a flow regime designed to maintain a river in certain agreed ecological condition (George B., et al., 2011). The term should always be used in plural, implying that a synonym to environmental flows is an ecologically acceptable flow regime designed to maintain a river in an agreed or predetermined state (Smakhtin \& Anputhas, 2006). The economically valuable commodities and services (ecosystem services) provided by functionally intact and biologically complex freshwater ecosystems, beyond simply direct water supply, include flood control, transportation, recreation, purification of human and industrial wastes, habitat for plants and animals, and production of fish and other foods and marketable goods (Flint, 2004). Each of these services requires its own minimum flow requirements, which should be determined based on seasonal variability of flow regimes across the year, and, hence, the phrase 'environmental flows'.

The Earth Summit in Rio de Janeiro in 1992 promoted the conservation of ecosystems as a public good, independent of their utility as a resource. A logical extension to this is to grant water rights to species and ecosystems, alongside the rights demanded by mankind (Acreman \& J.Dunbar, 2004). In principle, the downstream impacts from infrastructure investments should be assessed as part of project planning and design studies, including EIAs or other appropriate planning instruments. However, in practice, these downstream impacts have not always been fully recognized or accounted for, and their assessment has often arisen as a separate process, through Environmental Flows Allocation (EFA), specifically to fill this gap (Hirji \& Davis, 2009). This insures the success of IWRM, which depends on striking a balance between ecosystem health and human demand (Bakker, 2012 cited in Liu, et al., 2013).

Dams and reservoirs, aqueducts, river diversions, major irrigation projects, industrial and domestic diversions, groundwater pumping, etc have a major hydrological impact which could affect both present and future generations and wildlife (George, et al., 2008). However, according to American Society of Civil Engineers (1998), multifaceted objectives should be met by sustainable water resources systems; the two broader classifications of objectives being fully contributing to the objectives of the society across generations, and maintaining their ecological, environmental, and hydrological integrity. Environmental flows can therefore be seen as a compromise between river basin development on the one hand and the maintenance of river ecology on the other (Smakhtin and Eriyagama, 2008, cited in George B., et al., 2011).

Environmental flows are increasingly being recognized as vital in order to maintain healthy, productive, and sustainable river and groundwater systems (Hirji \& Davis, 2009). Deliberations about water allocation should, therefore, always include provisions for maintaining the integrity of freshwater ecosystems, including the need to maintain minimum in-stream flows and to anticipate the impact of hydrologic modifications on downstream environments (Flint, et al., 1996). This could be achieved through prior assessment of environmental water demand as one of the main components of environmental impact assessment of water resources development, owing to the mere fact that overriding this task will eventually result in long lasting undesirable consequences. This will leave us with few safeguards that will protect the systems that sustain us (Flint, 2004). Hence, conducting environmental flows assessment as one major parameter of EIA of water resources development and thereby allocating sufficient amount of water that can sustain the environment would mitigate many of the negative impacts on the downstream part of the dam/reservoir.

There are different ways of estimating environmental flows allocations. According to Acreman and J.Dunbar (2004), the approaches developed in various countries around the world to define environmental flows allocations can be divided into four categories:

- Look-up tables

- Desktop analysis

- Functional analysis

- Hydraulic habitat modeling

Among these methods, the desktop analysis methods generally focus on analysis of existing data. However, in some cases, they may use data from hydrological models. The methods can be sub-divided into those based purely on hydrological data, and those that employ both hydrological and ecological data.

Hughes and Munster (2000) and Hughes and Hannart (2003), cited in Acreman and Dunbar (2004), developed a desktop method to provide initial estimates of environmental flows needs for rivers in South Africa. According to the authors, the user calculates a hydrological index (i.e. coefficient of variation of flows divided by the proportion of total flow that is base flow: $\mathrm{CV} / \mathrm{BFI})$ using river flow data at the site, and then, curves are employed to define the percentage of mean annual runoff (MAR) volume that is required for different components (low flows and floods) of the environmental flows regime. Their model can be used for similar watersheds by customizing to local situations (McCartney, et al., 2010).

Dam Breach Analysis as a Component of EIA: Breach is defined as the opening formed in the dam body that leads the dam to fail and this phenomenon causes the concentrated water behind the dam to propagate towards downstream regions (Xiong, 2011). The statistical analysis of 534 dam failures from 43 countries before 1974 indicated that earth-rock dam failures accounted for the largest proportion of all failures and included $49 \%$ caused by overtopping, $28 \%$ seepage in dam body and $29 \%$ seepage in foundation (You, et al., 2012). As the EIA is the technical key to incorporating concepts such as the precaution principle and to preventing the loss of natural (and manmade) resources, which is evidently the main goal of sustainable development in decision-making (Toro, et al., 2013), it could be argued that catastrophic events resulting from dam breach are one of the major detrimental impacts of the dam construction, and hence, should be the subject of EIA. 
Dams provide many benefits for our society, but floods resulting from the failure of constructed dams have also produced some of the most devastating disasters of the last two centuries (Xiong, 2011). In many countries, the determination of the parameters of the wave, likely to be produced after the failure of a dam, is required by law (Molinaro, 1991; Betamio de Almeida and Bento Franco, 1993), and systematic studies are mandatory (GarciaNavarro, et al., 1999). Since catastrophic events due to dam failure are often of global concern, dam breach analysis, flood wave propagation and inundation mapping, as a component of EIA should be an issue of universal deliberation.

Case studies show that dam failure may arise due to different reasons ranging from seepage, piping (internal erosion), overtopping due to insufficient spillway capacity and insufficient free board and to settlement due to slope slides on the upstream shells and liquification due to earthquakes (Xiong, 2011). Hence, establishment and perfection of a modern Dam Safety Management (DSM) system is imperative. Modern DSM needs sound regulations and guidance, advanced safety management mode and related technologies (dam-break process modeling, flood propagation modeling, risk assessment technologies, etc.), all of which are established based on the achievements of dam-break research (You, et al., 2012).

Dam breach analysis for any foreseeable reasons should be conducted right at the design phase of the project, as one of the major components of the EIA of the project. Because, dam failure disasters and potential threats highlight the need for forecasting, prevention and reduction of dam-break disasters (You, et al., 2012), and development of effective emergency action plans requires accurate prediction of inundation levels and the time of flood wave arrival at a given location (Xiong, 2011).

In spite of numerous studies, there exists a knowledge gap in identifying vulnerable locations due to dam failure and applying the results to enhance activities in planning and developmental fields (Yerramilli, 2013). However, simulation of dam break events and the resulting floods are crucial to characterizing and reducing threats due to potential dam failures (Xiong, 2011). For many practical applications, it is accepted that the unsteady flow of water in a one-dimensional (1D) approach is governed by the shallow water or St. Venant equations. These represent the conservation of mass and momentum along the direction of the main flow (Garcia-Navarro, et al., 1999). The two primary tasks involved in the hydraulic analysis of a dam breach are the prediction of the reservoir outflow hydrograph and the routing of that hydrograph through the downstream valley (Xiong, 2011).

\section{Application of GIS-RS and Simulation Models in EIA of Water Resources Development}

Geographic Information Systems (GIS) is defined by USGS (2005) as "a computer system capable of assembling, storing, manipulating, and displaying geographically referenced information, i.e., data identified according to their locations" (Rhind, 1998 cited in Lo and Yeung, 2007). Geographic Information Systems are databases that usually have a spatial component to the storage and processing of the data. Hence, they have the potential to both store and create map-like products. They also offer the potential for performing multiple analyses or evaluations of scenarios such as model simulations (Lyon, 2003).

A number of computer models developed by different organizations have been used in water resources and environmental planning. GIS is broadly used in coupling with simulation models to offers a spatial representation of water resource geographical systems, and it has the ability to present an integrated view of the world (McKinneya \& Cai, 2002), while a simulation model is a representation of a system used to predict its behaviour under a given set of constraints (Teklu, et al., 2009).

Prediction step in EIA requires the greatest degrees of scientific application (Siddiqui, et al., 2008). Many of the simulation models can be coupled to GIS by adding GIS layers to provide clarity of impact. The USACE Hydrologic Engineering Center's River Analysis System (HEC-RAS) is one such model. GIS helps in visualizing flood simulations in an interactive setting, where the spatial impact of various scenarios can be viewed along with the location of critical facilities and, thus, helps in assessing the region's vulnerability towards a flood event efficiently (Yerramilli, 2013).

There are several strategies for coupling an environmental model to a GIS. These can range from a loose to a tight coupling. A loose coupling is where data are transferred between models and GIS, and each has separate database management capabilities and systems. A tight coupling is where data management in the GIS and model are integrated and they share the same database (Fedra and Kubat, 1996; Djokic and Maidment, 1993, cited in McKinneya and Cai, 2002).

The dam (inline structure) breach option of HEC-RAS allows the user to perform a Dam Breach analysis (Brunner, 2010). Xiong (2011) explains break parameters prediction, the understanding of dam break mechanics, peak outflow prediction as essential for the dam break analysis, and eventually determined the loss of the damages; and applied the dam break tool in HEC-RAS to Foster Joseph Sayers Dam break simulation and analysis based on given geometry data. The conclusion was that dam break is a complicated and comprehensive process involving lots of principles. Accordingly, Xiong (2011) mentions that combination of mechanics and case studies, reflection of predominant mechanisms of headcut erosion, more specific categorization of dam, prudent investigation and inference of dam break process are needed in developing a satisfactory dam break simulation model.

The degree to which water resources and environmental planning task is successful, reliable and credible depends on the availability and quality of data to be used. Environmental planning of water resources development involves a wide range of geographic areas with a variety of topographic features. Hence, it is often difficult to obtain physically measured and detailed topographic data, sufficiently representing the area of interest, owing to time, cost, etc., constraints.

In such instances, topographic and land use data can be extracted from remotely sensed digital elevation models and analysed in GIS environment. The study conducted by Gichamo, et al. (2012) on the approach to generate river cross-sections from the Advanced 
Spaceborne Thermal Emission and Reflection Radiometer Global Digital Elevation Model (ASTER GDEM) is worth mentioning. They discussed methods which are useful where accurate river cross sections and detailed floodplain information from surveying or high resolution aerial images are not available. The methods are indeed very useful for environmental planning of water resources development in large river basins of some geographic areas where topographical data are rarely available.

\section{Major Challenges in EIA and Environmental Planning of Water Resources Development}

Population Pressure: Population growth is a major contributor to water scarcity. Population growth yields heightened demands on air, water and land environments, because they provide necessary resources and act as sinks for environmental pollutants, emanating from the inherent link between population size and the environment as a result of individual resource needs as well as individual contributions to pollution needs as well as individual contributions to pollution (Hunter, 2000).

Population growth limits the amount of water available per person, drives people into marginal regions-which are already water stressed-and also into cities (Population Action International, 2011). Growth in populations means mounting demand and competition for water for agricultural, domestic, industrial, and municipal uses. Water is also needed for the evacuation of waste materials. Hence, it is implied that population pressure limits the per capita available freshwater for all these services, resulting in further socio-economic and environmental deterioration.

The report of the United Nations (United Nations, 2013), shows that the current world population of 7.2 billion is projected to increase by 1 billion over the next 12 years and reach 9.6 billion by 2050 , the growth being mainly in developing countries, with more than half in Africa. It is predicted that the global population increase to the year 2025 alone would require an expansion of food production of about $40-45 \%$ (Stockle, 2001). This would require expansion of agricultural land and extensive use of additional freshwater, among other possible solutions, both at the expense of the environment.

As the demand for water resources of sufficient quantity and quality for different purposes continues to intensify due to population growth, dams, aqueducts and other kinds of water infrastructure will still have to be built, particularly in developing countries where basic human needs have not been met (Flint, 2004). Hence, the increase in population number, if realized to happen as it has been forecasted, will result in an immense detrimental environmental impact. It will have direct negative consequences on the environment, as it results in expansion of agricultural land and urban areas, increased competition on and over-exploitation of natural resources, annexure of the habitats of terrestrial and aquatic wildlife, migration and thereby extinction of rare fauna and flora, etc. Population growth, along with associated developments, will result in the doubling of global food demand by 2050 (Population Action International, 2011). This will require increased agricultural production and put increased pressure on land and water resources. The increased pressure on water resources will, in turn, result in reduced environmental flows and all the negative effects related to it.
Climate Change: Climate change can affect the quantitative and qualitative status of water resources by altering hydrological cycles and systems. Changes in these variables lead to impacts on all the socio-economic and environmental goods and services that depend on these variables directly or indirectly (Filho, 2012).

Possible impacts of climate change that may especially affect water resources planning and project evaluation include changes in precipitation and runoff patterns, sea level rise, and land use and population shifts that may follow from these effects (Frederick \& Major, 1997). Sustainable water resources development has to address the issue of managing and living with hydrologic extremes, extremes that are likely to increase in magnitude and frequency if global climate change research results are to be believed (ASCE, 1998). However, the global climate change research results should be translated into local scenarios for relevant policies and mitigation strategies to be in place. How climate change will affect local situations situation should be clear.

For instance, climate change will definitely result in increased or decreased rainfall. If rainfall increases then there may be benefits for crop yields, although these may be offset by increased variability and soil erosion due to higher rainfall intensities, if rainfall decreases food security is likely to deteriorate (Conway, 2005). Remedial actions will be effective if the outcome of climate change is predictable; and the predictability will, at large, emanate from studies and researches which account for global climate change speculations as translated into local context. On a study conducted to evaluate the downstream implications of planned water resources development in the Ethiopian portion of the Blue Nile, McCartney and Girma, (2012) commented that scant attention has been paid to the possible water resource implications of climate change. It can also be inferred that the other environmental considerations were hardly sufficiently addressed. Under such circumstances, it would be difficult to formulate policies addressing problems arising from climate change.

ILL-conceived Planning: Although the development of water resources through dams (small and large), interbasin transfers, aquifer storage and recovery, levees and dikes, and boreholes provides a buffer against climate variability (Hirji \& Davis, 2009), and sustain human existence, ill-conceived water storage structures constructed today will be a waste of scarce financial resources, and may aggravate unpleasant climate change impacts rather than mitigating it (McCartney et al., 2013). The realities of climate change are such that if the performance of agricultural water storage is to be enhanced in the future, much closer attention must be paid to planning and management (ibid.).

Water problems of the world are neither homogenous, nor constant or consistent over time: they often vary significantly from one region to another, even within a single country, from one season to another, and also from one year to another (Biswas, 2004). Hence, the planning approach at one particular time range or geographic area may not exactly fit-in to solve the problems of the others.

Integrated Water Resource Management (IWRM), in which EIA of water resources development should be 
incorporated, is emerging as an accepted alternative to the sectoral, top-down management style that has disastrously dominated in the past (Castelletti, et al., 2008). While strongly influenced by financing agencies' policies, there is a growing recognition that top-down management plans do not always work well, and that increased attention must be given to user-driven directions-emphasizing cost-recovery, financial management, and operation and management of the constructed systems. There is little doubt that there is, and will continue to be, a growing emphasis on giving water user groups more responsibility in the management of the systems (ibid.). In order to exploit local traditional development and management skills in natural resources management and mitigation of negative environmental impacts of water resources development, the public should involve in the planning process.

IWRM is based on the recognition that the intrinsic complexity of interconnected biophysical, social, economic and political factors can only be addressed by combining and truly integrating social constructivist ideas of participation and empowerment with a crossdisciplinary engineering approach (Castelletti, et al., 2008). As much as the adaptive ecosystem approach requires a holistic view of the ecological and socioeconomic aspects of an entire landscape, it also requires an integrated institutional and fully participatory planning and decision making process (ASCE, 1998). The community affected by a development project should be previously informed so that its members can participate in the decision-making processes (Toro, et al., 2013).

Many of the water problems have already become far too complex, interconnected and large to be handled by any one single institution, irrespective of the authority and resources given to it, technical expertise and management capacity available, level of political support, and all the good intentions (Biswas, 2001 cited in Biswas, 2004). Now a days, participatory approach in water resources planning, which is particularly proposed by national and international water authorities such as European Environmental Agency and US Environmental Protection Agency (EPA, 2003 cited in (Yurdusev \& O'Connell, (2005), is typically favoured.

Participatory methods are widely seen as essential to address the difficulties of environmental policy and decision-making (Lienert, et al., 2013). Public participation is a key IWRM element that can be characterized by different levels of stakeholder engagement (De Stefano, 2010 cited in Liu, et al., 2013). Despite the recognition of EIA's importance, public participation in the EIA process is often regarded as ineffective, due to time, budget, resource, technical and procedural constraints, as well as the complexity of environmental information (Lei and Hilton, 2013). However, according to (Siddiqui, et al., 2008), the initial cost and efforts for EIA should be considered as an investment in the overall project development. Public participation can include the design and implementation of processes for seeking public opinions, reviews of, and comments on, proposed governmental agency actions (ASCE, 1998).

In view of increasing future dynamics and climate change, a more participatory and long-term planning approach is required (Lienert, et al., 2013). Consequently, in contrast to the past, planning needs to be much more integrated across a range of levels and scales, with much greater consideration of the full range of possible options and the potential implications of climate change (McCartney, et al., 2013). In this respect, a follow-up study of the EIA for Koga Irrigation scheme in Ethiopia found that almost nonexistent public participation in decision-making was a major constraint to implementation of EIA recommendations (Abebe et al. 2008 cited in McCartney, et al., 2010). Therefore, the existence of EIA documents alone is not a sufficient condition for sustainability, but EIA studies should be conducted through active participation of the public and the result of EIA should be made available to decision makers, technological experts and the public (Siddiqui, et al., (2008).

Policies and Institutions: Solutions to water problems depend not only on water availability, but also on many other factors, among which are the processes through which water is managed, competence and capacities of the institutions that manage them, prevailing sociopolitical conditions that dictate water planning, development and management processes and practices, appropriateness and implementation statuses of the existing legal frameworks, availability of investment funds, social and environmental conditions of the countries concerned, levels of available and usable technology, national, regional and international perceptions, modes of governance including issues like political interferences, transparency, corruption, etc., educational and development conditions, and status, quality and relevance of research that are being conducted on the national, subnational and local water problems (Biswas, 2004).

The influence of policies and institutions on the success or failure of interventions can be seen in many ways-on poverty and equity impacts, in implementation, and in the sustainability of interventions. Interventions designed to alleviate poverty and enhance growth fail for a variety of reasons, many of which are related to the policies and broader social institutions that determine an individual's access to resources and the distribution of the benefits of publicly-financed interventions (Haileslassie, et al., 2008).

According to Rockström, et al. (2010), several studies indicate that supplemental irrigation systems are affordable for small-scale farmers, if policy frameworks, institutional structures, and human capacities similar to those for full irrigation infrastructure are in place to successfully apply supplemental irrigation in rainfed agriculture. Policies and institutions are critical for the implementation of interventions, as they create an environment and incentives that can either enable or undermine them. Policies such as agricultural subsidies and institutions such as land ownership determine the landscape within which production decisions, and, hence, land and water management practices, are considered (Haileslassie, et al., 2008).

Institutions are a combination of policies and objectives: laws, rules and regulations; organizations, their bylaws and core values; operational plans and procedures; incentive mechanisms; accountability mechanisms; and norms, traditions, practices and customs (Haileslassie, et al., 2008). Institutions should mean not only formal organizations, but also informal ones and their laws, customs and social practices that 
influence people's behavior in a society or economy (ibid.).

The time is fast approaching when water can no longer be viewed in isolation by one institution or any one group of professionals without explicit and simultaneous consideration of other related sectors and issues and vice versa (Biswas, 2004). In some cases, it cannot be easily handled by formal (governmental) institutions either. Traditional administrative, management, religious, etc. institutions have vital roles to play in mobilizing local resources and indigenous knowledge, and bridge between external development interventions and endogenous development.

In a study conducted to assert the role of traditional authorities in the effectiveness of Water Users Associations (WUAs) in the management of communitybased irrigation schemes in Northeastern Ghana, Derbile (2012) reported the following results:

$\checkmark$ The executive structures of WUAs gain legitimacy and derive power to operate in communities because they have the consent and support of traditional authorities,

$\checkmark$ Traditional authorities are directly involved in certain operational and management functions of the community irrigation projects in support of the functioning of WUAs.

$\checkmark$ Traditional authorities support resource mobilization for supporting maintenance initiatives of WUA executives.

$\checkmark$ Another area in which traditional authorities support the work of WUAs is in the area of setting rules, enforcing rules and conflict resolution.

Hence, Derbile, (2012) sheds light on the contributions of Traditional Authorities (TAs) in the existing management arrangements of community-based irrigation schemes in northeastern Ghana, which, undoubtedly, holds good for other natural resources and environmental planning and management activities. But, formal institutions should be smart enough to exploit the potentials of the informal institutions as change agents.

There should also be appropriate policy definitions in place in order to properly tap the available natural and social resource potentials. In this respect, the study conducted by Ruffeis, et al. (2010) on the Ethiopian Environmental Policy with focus on the institutional set-up and implemented Environmental Impact Assessment (EIA) procedures, witnessed that specific legal provision for EIA applications exists and is well documented; and the Environmental Protection Authority (EPA) is the legal body to control and realize environmental policies and the implementation of the EIA system. However, Ruffeis, et al. (2010) conclude that awareness of environmental issues is generally low at policy level, which is manifested through inconsistency at institutional level, the lack of complementarities between institutions, and between environmental and investment policy and proclamations, contradicting the enforcement of EIA law and making it ineffective in practice.

Ruffeis, et al., (2010) accounts this institutional weakness to a donor-driven nature of the evolution of the policies, rather than a genuine political will. Similarly, on the study conducted to explore processes of climate variability, climate change and adaptation acting across a range of spatial and temporal scales taking the Nile Basin as a unit of analysis, Conway (2005) points out that the critical outcome of government policies must be to help enable Ethiopian farmers move from subsistence coping to more productive, less climatically sensitive, agricultural methods and to enhance their opportunities to diversify their income generating activities. But, critical outcome of government policies should basically emanate from appropriate research and critical analysis of the real situation. Therefore, the mere existence of policy documents and institutional units is not sufficient to enforce local and global initiatives to safeguard the environment and thereby the human welfare against deterioration. It goes without saying that the adoption and application of EIA depends on the institutional framework and the political context in the country or region (Ortolano et al., 1987 cited in Toro, et al., 2013).

\section{CONCLUSIONS}

Environmental Impact Assessment (EIA): is a decisionmaking process that systematically evaluates the possible significant (negative or positive) effects that a proposed project action may exert on the natural, social and human environment of a particular geographic area. It is, thus, possible that the EIA of a water resources development, like any other development projects, can end up with a 'reject' proposal and decision if the results of the analyses show that the project will have severe detrimental impacts.

Sustainable water resources development and the environment: The sustainable development of water resources is a multi-dimensional way of thinking about the connections or interdependencies among natural, social, and economic systems in the use of water. Hence, there is, as such, no credible sustainability where the environmental impact of the project has not been properly evaluated and mitigating measures have not been proposed in cases of adverse environmental impacts of the project.

Environmental Flows Assessment: Sustainable water resource systems are required to simultaneously contribute to the objectives of society, now and in the future, and maintaining their ecological, environmental, and hydrological integrity. As one of the legitimate users of water, the environment should be allotted sufficient amount of water for its sustainability, based on seasonal variability in water demand. Continuous supply of water, proportional to the natural flow regimes across different seasons is the basis for sustainability of the whole ecosystems. Hence, environmental flows assessment and allocation of water for ecological water demand should be mandatory before granting permission for construction of water resources development. Sustaining the environment by allotting sufficient amount of water is sustaining life on the planet, including human being.

Dam breach flood wave propagation and inundation mapping: Breach is defined as the opening formed in the dam body that leads the dam to fail and this phenomenon causes the concentrated water behind the dam to propagate towards downstream regions. As the EIA is the technical key to incorporating concepts such as the precaution principle and to preventing the loss of natural and manmade resources, which is evidently the main goal of sustainable development in decision-making, catastrophic events resulting from dam breach are one of 
Tena Bekele and Srinivasa Rao

the major detrimental impacts of the dam construction, and hence, dam breach analysis, flood wave propagation and inundation mapping should be incorporated in the EIA report of water resources development projects, together with appropriate mitigation measures to support decision making and follow up by the public. The efforts being made in some countries to legislate the determination of the parameters of the wave likely to be produced after the failure of a dam should be encouraged and made universal.

Application of GIS-RS and simulation models in EIA of water resources development: The degree to which water resources and environmental planning task is successful, reliable and credible depends on the availability and quality of data to be used. Environmental planning of water resources development involves a wider range of geographic areas with a variety of topographic features. EIA of water resources development involves the collection, analysis, modeling and mapping of multitude of socio-economic, natural and manmade environmental data. However, it is often difficult to obtain the whole set of measured and surveyed environmental data. Hence, the analysis of remotely sensed data in GIS environment plays a role of paramount importance in acquiring and analyzing environmental data.

Some of the challenges in EIA and environmental planning of water resources development: Population pressure, climate change, ill-conceived planning and lack of appropriate policies and institutions are some of the challenges to sustainable environmental planning of water resources development. These parameters are subjects of national and international interest, and therefore, need full commitment of governments' respective policies, laws, rules and regulations to address these parameters properly.

The importance of integration and public participation in EIA of water resources development: Water and other environmental resources related to it can no longer be viewed in isolation by one institution or any one group of professionals without explicit and simultaneous consideration of other related sectors and issues and vice versa. Hence, it is important to address issues related to water in integration with other environmental resources. The public at large has closer associations to the environment than formal organizations constituted by high level expertise. Besides, the public has its own ways of understanding and addressing environmental problems. Hence, public participation in decision making and management of environmental issues should be rendered adequate attention.

Appropriate policies and institutions: There should also be appropriate policy definitions and proper institutional setup in place in order to properly tap the available natural and social resource potentials. Besides formal (governmental or non-governmental) institutions, traditional ones have a great role to play in bridging external interventions and the public regarding environmental planning and management.
Sci. Technol. Arts Res. J., April-June 2014, 3(2): 180-189

\section{REFERENCES}

Abbasi, S. (2001). Water Resources Projects And Their Environmental Impacts. New Delhi: Discovery Publishing House.

Acreman, M., and Dunbar, M. (2004). Defining Environmental River Flow Requirements-A Review. Hydrology and Earth System Sciences 8(5): 861-876.

Baba, K., and Hirose, T. (2014, January 5). Environmental Impact Assessment of Dams and Reservoirs. Retrieved from UNESCO-EOLSS: http://www.eolss.net/samplechapters/c07/e2-12-02-01.pdf

Biswas, A.K. (2004). Integrated Water Resources Management: A Reassessment. Water International 29(2): 248-256.

Brunner, G.W. (2010). HEC-RAS: River Analysis System Version 4.1 User's Manual. USA: US Army Corps of Engineers Institute for Water Resources Hydraulic Engineering Center.

Castelletti, A., Pianosi, F., and Soncini-Sessa, R. (2008). Integration, participation and optimal control in water resources planning and management. Applied Mathematics and Computation 206: 21-33.

Conway, D. (2005). From headwater tributaries to international river: Observing and adapting to climate variability and change in the Nile basin. Global Environmental Change 15: 99-114.

Derbile, E.K. (2012). Water Users Associations and Indigenous Institutions in the Management of Community based Irrigation Schemes in Northeastern Ghana. European Scientific Journal 118-135.

Dong, C., Schoups, G., and Giesen, N. V. (2013). Scenario Development for Water Resources Planning and Development: A Review. Technological Forecasting and Social Change 80: 749-761.

FAO. (2011). The State of the World's Land and Water Resources for Food and Agriculture: Managing systems at risk. New York: The Food and Agricultural Organization of the United Nations.

Filho, W. L. (2012). Climate Change and the Sustainable Use of Water Resources. Berlin: Springer.

Flint, R. (2004). The Sustainable Development of Water Resources. Water Resources Update 127: 48-59.

Frederick, K.D., and Major, D.C. (1997, September). Climate Change and Water Resources. Climate Change And Water Resources Planning Criteria 7-22.

Garcia-Navarro, P., Fras, A., and Villanueva, I. (1999). Dambreak flow simulation: some results for one-dimensional models of real cases. Journal of Hydrology 216: 227-247.

George, B., Malano, H. M., and Davidson, B. (2008). Water resource allocation modelling to harmonise supply and demand in the Malaprabha catchment, India. 13th IWRA World Water Congress. Montpellier: International Water Resources Association.

George, B., Malano, H., Davidson, B., Hellegers, P., Bharati, L., and Massuel, S. (2011). An integrated hydro-economic modelling framework to evaluate water allocation strategies I: Model development. Agricultural Water Management 98: 733-746. 
Tena Bekele and Srinivasa Rao

Gichamo, T., Popescu, I., and A. Jonoski, D. S. (2012). River cross-section extraction from the ASTER global DEM forflood modeling. Environmental Modelling and Software 31: $37-46$.

Griffin, R. C. (2006). Water Resource Economics: The Analysis of Scarcity, Policies, and Projects. London: MIT Press.

Haileslassie, A., Hagos, F., Mapedza, E., Sadoff, C., Seleshi Bekele Awulachew, S. G., and Peden, D. (2008). Institutional Settings and Livelihood Strategies in the Blue Nile Basin: Implications for Upstream/Downstream Linkages. IWMI Working Paper 132. Colombo, Sri Lanka: International Water Management Institute.

Hirji, R., and Davis, R. (2009). Environmental Flows in Water Resources Policies, Plans and Projects: Findings and Recommendations. Washington, DC: The World Bank.

Hunter, L. M. (2000). The Environmental Implications of Population Dynamics. Santa Monica, CA: RAND.

IWMI. (2013). Agricultural Water Storage in the Era of Climate Change: Assessing Need and Effectiveness in Africa. Colombo, Sri Lanka: International Water Management Institute.

Jain, S., and Singh, V. (2003). Water Resources Systems Planning and Management: Development in Water Science. Amsterdam, The Netherlands: Elsevier Science B.V.

Lei, L., and Hilton, B. (2013). A Spatially Intelligent Public Participation System for the Environmental Impact Assessment Process. ISPRS International Journal of Geo-Information 2: 480-506.

Lienert, J., Schnetzer, F., and Ingold, K. (2013). Stakeholder analysis combined with social network analysis provides fine-grained insights into water infrastructure planning processes. Journal of Environmental Management 125:134-148.

Liu, S., Crossman, N. D., Nolan, M., and Ghirmay, H. (2013). Bringing ecosystem services into integrated water resources management. Journal of Environmental Management 129: 92-102.

Lo, C., and Yeung, A. K. (2007). Concepts and Techniques of Geographic Information Systems, Second Edition. New Jersey: Pearson Education Inc.

Loucks, D. P. (2009). Sustainable Water Resources Management. Water International 25(1): 3-10.

Lyon, J. G. (2003). GIS for Water Resources and Watershed Management. London and New York: Taylor and Francis.

McCartney, M. P., and Girma, M. M. (2012). Evaluating the downstream implications of planned water resource development in the Ethiopian portion of the Blue Nile River. Water International 37(4): 362-379.

McCartney, M., Alemayehu, T., Shiferaw, A., and Awulachew, S. B. (2010). Evaluation of Current and Future Water Resources Development in the Lake Tana Basin, Ethiopia. Colombo: International Water Management Institute.

McCartney, M., Rebelo, L.-M., Xenarios, S., and Smakhtin, V. (2013). Agricultural Water Storage in an Era of Climate Change: Assessing Need and Effectiveness in Africa. Colombo, Sri Lanka: International Water Management Institute.

McKinneya, D. C., and Cai, X. (2002). Linking GIS and water resources management models: an object-oriented
Sci. Technol. Arts Res. J., April-June 2014, 3(2): 180-189 method. Environmental Modelling and Software 17: 413425.

Nel, J.L., Turak, E., Linke, S., and Brown, C. (2011). Integration of environmental flow assessment and freshwater conservation planning: a new era in catchment management. Marine and Freshwater Research 62: 290299.

Population Action International. (2011). Why PoPulation Matters to Water Resources. Washington, USA.

Rockström, J., Karlberg, L., Wani, S. P., Barron, J., Hatibu, N., Oweis, T., Qiang, Z. (2010). Managing water in rainfed agriculture-The need for a paradigm shift. Agricultural Water Management 97: 543-550.

Ruffeis, D., Loiskandl, W., Awulachew, S. B., and Boelee, E. (2010). Evaluation of environmental policy and impact assessment process in Ethiopia. Impact Assessment and Project Appraisal 28(1): 29-40.

Siddiqui, N., Shukla, R., and Ziauddin, A. (2008). Environmental impact assessment (EIA) for a water resource project. Ecology, Environment and Conservation 14(4): 707-711.

Smakhtin, V., and Anputhas, M. (2006). An Assessment of Environmental Flow Requirements of Indian River Basins. Colombo: International Water Management Institute.

Stockle, C.O. (2001, Fall 2). Environmental Impact of Irrigation: A Review. Retrieved from State of Washington Water Research Center: http://www.swwrc.wsu.edu/ newsletter/fall2001/Irrlmpact2.pdf

Teklu, E., Seleshi, B., Haileslassie, A., and Aster, D. (2009). Impacts of Improving Water Management of Smallholder Agriculture in the Upper Blue Nile Basin. CP 19 Project Workshop (pp. 7-21). Addis Ababa: International Water Management Institute.

The American Society of Civil Engineers (ASCE). (1998). Sustainability Criteria for Water Resource Systems. Virginia: The American Society of Civil Engineers.

Toro, J., Requena, I., Duarte, O., and Zamorano, M. (2013). A qualitative method proposal to improve environmental impact assessment. Environmental Impact Assessment Review 43: 9-20.

United Nations. (2006, August). Coping with Water Scarcity. New York: United Nations.

United Nations. (2013, June 13). UN News Centre. Retrieved from United Nations: http://www.un.org/apps/news/ story.asp?NewsID=45165\#.UxHJdoX3ODG

Xiong, Y. (2011). A Dam Break Analysis Using HEC-RAS. Journal of Water Resource and Protection 3: 370-379.

Yerramilli, S. (2013). Potential Impact of Climate Changes on the Inundation Risk Levels in a Dam Break Scenario. ISPRS International Journal of Geo-Information 2: 110134.

You, L., Li, C., Min, X., and Xiaolei, T. (2012). Review of Dam-break Research of Earth-rock Dam Combining with Dam Safety Management. International Conference on Modern Hydraulic Engineering (pp. 28: 382-388). Wuhan: Procedia Engineering.

Yurdusev, M.A., and O'Connell, P.E. (2005). Environmentally Sensitive Water Resources Planning. Water Resources Management 19: 375-397. 